\title{
The Effects of Weather Modification on North- ern Great Plains Grasslands: A Preliminary
}

Assessment

\section{DAVID A. PERRY}

Highlight: Possible effects of weather modification on Northern Great Plains Grasslands are examined using published reports on community-water relations. It is concluded that (1) long-term incremental forage production will be governed by the effect of added water on nutrient cycling rates; (2) community composition will change, but the nature of the change will depend on the timing of added precipitation; and (3) increased forage in the absence of increased nitrogen may have a neutral or negative effect on livestock weight gains.

The use of cloud seeding to increase growing season rainfall is receiving a great deal of attention in the semiarid West. In the Northern Great Plains, both North and South Dakota are seeding clouds on a large scale operational basis, and the Bureau of Reclamation recently initiated a major experimental program in Montana. Not only is purposeful change in the region's weather a growing possibility, but inadvertent weather modification will likely emerge as one of the probable spinoffs from increasing industrialization in the area.

In cultivated crops, which are relatively simple ecological systems, and in which man has a large number of management options, the results of changing weather can be anticipated with fair (though not exact) certainty (cf. Caprio and Williams, 1973). The complexity of the rangeland ecosystem, however, suggests that its response to added water will not be so easily predicted.

This paper reviews, for the Northern Great Plains, the litcrature on the relation betwcen grasslands and water. The objective is an estimation of the effect added water will have on these range ecosystems. Based on this literature, I will deal

During the research the author was range ecologist, Montana Department of Natural Resources and Conservation, High Plains Program, Miles City. At present he is research forester, U.S. Department of Agriculture, Forest Service, Intermountain Forest and Range Experiment Station, Ogden, Utah 84401 , stationed in Bozeman, Mont., at the Forestry Sciences Laboratory, maintained in cooperation with Montana State University.

This work was funded by the Atmospheric Water Resources Division, U.S. Bureau of Reclamation, and Intermountain Forest and Range Exp. Sta., U.S. Dep. Agr., Forest Service. The author wishes to thank Don Ryerson, Kris Aase, Frances Siddoway, Ross Wight, Al Black, Earl Neff, Walt Mueggler, Arlin Super, Tad Weaver, Wyman Schmidt, and Joe Basile for reading and commenting on the manuscript.

Manuscript received July 29, 1975. with four questions: (1) What is the effect of increased rainfall on primary and secondary productivity? (2) What factors limit the response of grasslands to added water, and how will they be affected by increased rainfall? (3) How do different species respond to added water with various seasons of application, and how will the interaction of species response and seasonality affect the composition of the range? (4) How will changes in the weather affect community resistance to drought, plant and animal pathogens, and soil loss associated with runoff?

\section{Effect of Added Water on Primary Productivity}

Primary productivity of grasslands has been extensively studied in relation to increases in soil water. Two experimental techniques have been most often used: (1) comparison of rainfall and forage production using regression and correlation, and (2) irrigation, either by water spreading or sprinkling. Results have been mixed, making it difficult to generalize about rangeland response to added water.

Because regression techniques simulate plant response to increments in natural rainfall, they might be expected to give the most realistic estimate of the effect of weather modification on forage production. A number of studies have been conducted on northern grasslands. These have produced variable results, with differences in yield attributable to growing season rainfall ranging from $84 \%$ to less than $25 \%$ (Rogler and Haas, 1947; Smoliak, 1956; Dahl, 1963; Rauzi, 1964; Noller, 1968; Mueggler, 1972; Ballard and Ryerson, 1973). Where rainfall and forage production are significantly related, estimates of precipitation use efficiency have varied from approximately $50 \mathrm{lb}$ dry forage/acre-inch of available water (Thomas and Osenbrug, 1964) to $110 \mathrm{lb}$ dry forage/ acre-inch of water (Wight and Black, 1972).

The differences seen in these studies probably represent both experimental noise and biological variation. For example, if rain gauges are located separately from production sampling points, significant errors may enter into the analysis. On the other hand, the capacity to respond to added water certainly varies with time, space, and community type. It is the degree of this latter variation which is of interest. 
Irrigation studies, although normally adding more water than might be expected from cloud seeding, have the advantage of being controlled experiments. They therefore presumably minimize experimental noise and allow a more accurate estimate of the true variability in the response of rangeland to additions of water. A number of irrigation experiments have produced significant results. Two water spreading studies in southeastern Montana resulted in grass forage increases of approximately 300\% (Monson and Queensberry, 1958; Branson, 1956). Sprinkling in sufficient amounts to double growing season rainfall resulted in yield increases of $100 \%$ to $200 \%$ in western Montana (Klages and Ryerson, 1965), and 50\% in North Dakota (Smika et al., 1965). Lauenroth and Sims (1973) found that yields of shortgrass prairie in Colorado were increased approximately $100 \%$ when soil water stress at $10 \mathrm{~cm}$ was kept above -0.8 bars.

However, an impressive array of experiments have shown little or no increased production resulting from irrigation. Cosper and Thomas (1961) found yield increases of only $16 \%$ on a water-spreading study in South Dakota. In New Mexico, water spreading on sandy sites did not affect vegetative cover (Valentine, 1947). Weaver (1975) found that additions of water ranging from $140 \%$ of normal rainfall to maintaining a constantly wet soil increased production of Idaho fescue (Festuca idahoensis) meadows slightly when water was added in the spring, but not at all for summer additions. Bleak et al. (1974) compared yields on Utah grasslands receiving $150 \%$ and $67 \%$ of normal rainfall, and found no difference. Pettit and Fagan (1974) irrigated buffalograss (Buchloe dactyloides) in combination with various nitrogen treatments, and found lower yields in irrigated than in nonirrigated plots in all but one nitrogen treatment. In two studies of the effect of irrigation on below-ground biomass, no increased root growth was found as a result of added water (Lauenroth and Sims, 1973; Garwood, 1967). Garwood attributed this to a faster rate of decay of dead roots.

These results indicate that the response of grasslands to added water is complex and highly variable. An evaluation of the role which weather modification will play on western rangelands requires an understanding of the factors affecting this variability. Several of these are discussed below. They are: (1) nutrient limitations, (2) pattern of water application, and (3) genetic limitations.

\section{Factors Affecting the Grassland Response to Water}

\section{Nutrients}

Available forms of nutrients, especially nitrogen $(\mathrm{N})$ and phosphorus (P), are commonly in short supply in grasslands (Harmsen and Van Schreven, 1955). Range fertilization often results in dramatic increases in water use efficiency and forage production (Smika et al., 1965; Klages and Ryerson, 1965; Wight and Black, 1972; Lauenroth and Sims, 1973), and a number of investigators have concluded that $\mathrm{N}$ is more limiting than water on Northern Great Plains rangelands (White and Moore, 1972; Wight and Black, 1972; Lauenroth and Sims, 1973). Even where $\mathrm{N}$ isn't the most limiting factor, it may quickly become so when water availability is increased. Thus, rather than being a linear relation, forage yield as a function of water availability may asymptotically approach some maximum determined by available N (cf. Van Dyne, 1975). This would perhaps explain some cases of poor correlation between rainfall and forage production.
The effect which added precipitation has on nutrient availability is directly related to its effect on microbial activity. Soil $\mathrm{CO}_{2}$ evolution and/or nitrification are inhibited at 0 bars soil water tension, rise quickly at -.15 to -.50 bars, and then decline with further drying, although the decline may be slow and significant activity may continue at tensions as low as -15 bars (Parker and Larson, 1962; Justice and Smith, 1962; Miller and Johnson, 1964; Wiant, 1967; Nyhan and Doxtader, 1974). Koepf (1952) reported that the optimum water content for the activity of soil bacteria was $60-70 \%$ of field capacity.

If microbial activity is largely confined to a certain range in soil water tension, nutrient release should be correlated with the length of time soil water tension is within these ranges, and therefore to the pattern rather than simply the amount of rainfall. This theory is supported by Soulides and Allison's (1961) observations that decomposition rate was significantly increased by alternate wetting and drying of the soil. DeJong et al. (1974) found that the number of wetting and drying cycles in the soil was responsible for a large part of the annual variation in soil respiration. Wildung et al. (1973) found soil respiration rate highly correlated with soil moisture and temperature one year, but not the next. They suggested that differences in rainfall pattern between the two years might be an explanation. However, "few experiments have been designed to determine the influence of fluctuating soil water on microbial activity" (Nyhan and Doxtader, 1974).

Soil water may also affect microbial activity through its influence on soil temperature, which generally enters as an important variable in regressions of decomposition rate on native grasslands (Nyhan and Doxtader, 1974; DeJong et al., 1974). At least certain kinds of microbial populations are quite sensitive to temperature changes. Parker and Larson (1962) found that, in the temperature range $16^{\circ} \mathrm{C}$ to $20^{\circ} \mathrm{C}$, a $2^{\circ} \mathrm{C}$ change had a measurable effect on nitrification. At temperatures of $25^{\circ} \mathrm{C}$ to $30^{\circ} \mathrm{C}$, this wasn't observed. Water added during spring months may keep soil temperatures cooler and less favorable for microbial activity. In summer, added water may reduce extremely high soil temperatures and create more favorable decomposition conditions.

Increased rainfall will probably result in higher microbial activity and consequent higher rate of nutrient release. However, this may not be seen as increased nutrient concentration in the soil. Power (1972) has shown that as much as 350 $\mathrm{kg} /$ ha of added $\mathrm{N}$ can be immobilized by grasslands. Much of this immobilization is done by roots, however, and increased nutrient turnover leading to increased root growth will surely be beneficial to the rangeland community.

\section{Rainfall Pattern}

The effect of timing, frequency, and amount of rainfall from single storms has generally been neglected in range research (cf. Smith, 1972), although these factors have becn acknowledged as important in water use efficiency (Wight and Black, 1974), nutritive levels of grass (Rogler and Haas, 1947), community composition (Albertson and Tomanek, 1965), phenological events (Sundberg, 1974; Beatley, 1974), and insect response (Cooper and Jolly, 1969). Several authors have suggested that year-to-year differences in pattern of rainfall may explain the poor correlation between it and primary productivity (Wight and Black, 1974; Ballard and Ryerson, 1973). No experiment has been designed to specifically test this theory, and the role which rainfall pattern plays in 
grassland response remains largely speculative.

\section{Genetic Limitations}

Genetic factors apparently play a significant role in the ability of a grassland to respond to improved water or nutrient supplies. Wight and Black (1974) found that mixed prairie standing crop in eastern Montana peaked in mid-July regardless of the amount of soil water available at that time. They concluded that peak standing crop was genetically controlled and that maximum water use by this type of community was about $25 \mathrm{~cm}$. Weaver (1975) suggested that genetic control of the period during which the plant makes its growth may be a factor in the failure of Idaho fescue meadows to respond to summer irrigation. Late summer dormancy is apparently common in many grass species (Laude, 1953), and suggests that cloud seeding to increase rainfall in the late summer may either be nonproductive or result in significant shifts in species composition. This will be discussed in more detail later.

Many grass species apparently do not respond to additions of water. Ballard and Ryerson (1973) found that only four out of ten species in southeastern Montana were significantly influenced by precipitation, and in only one of these, western wheatgrass (Agropyron smithii), was more than $30 \%$ of variation in production explained by rainfall. In Kansas, Shiflet and Dietz (1974) found good correlations between rainfall and production in only one of four grass species.

Bradshaw et al. (1960) and Bradshaw (1964) postulated that grasses with low yields have a selective advantage in nutrient-poor situations. The evidence indicates that evolution in the rigorous environment of the Great Plains has similarly produced at least some species whose forage production is genetically fixed at fairly low levels. There are ample data to show that the grassland community will respond to improved growth conditions, especially greater nitrogen availability. But this response is not uniform among species, and such an amelioration of the environment would almost certainly result in shifts in species composition. The direction which these shifts may take are explored below.

\section{Effect of Added Water on Composition of the Range}

\section{Species Change}

The exact nature of changes in composition due to increased precipitation will undoubtedly vary among communities. Spring and early summer rains will probably favor the development of cool-season over warm-season grasses (Ballard and Ryerson, 1973). Late summer rains will perhaps do the opposite (Klages and Ryerson, 1965; Lauenroth and Sims, 1973); however, no experiment has specifically tested this. Forb production also appears to be favored by late summer and fall rains (Noller, 1968). Increased $\mathrm{N}$ and $\mathrm{P}$ availability will probably favor cool-season grasses and forbs (Williams, 1953; Cosper and Thomas, 1961; Goetz, 1969). ${ }^{1}$

Species composition of Great Plains grasslands normally changes with changing weather. The response of rangeland to drought has been thoroughly studied (Weaver and Albertson, 1939), but only one publication has documented species changes resulting from a several-year period of high rainfall. Coupland (1959) found that, during a period of unusually favorable weather on grasslands in southern Saskatchewan and Alberta, percent composition contributed by wheatgrasses and porcupine needlegrass (Stipa spartea) increased markedly,

\footnotetext{
${ }^{1}$ Also from personal communications with J. Ross Wight.
}

while blue grama (Bouteloua gracilis) and needleandthread (Stipa comata) decreased. Porcupine needlegrass actively invaded sites which had formerly been too dry.

Experiments which modify water availability give further insights into possible shifts in species composition due to weather modification. Pitting and scalping studies in northern Montana, which increased both water and $\mathrm{N}$ availability, resulted in shifts of dominance from needleandthread to western wheatgrass. In some cases, these treatments have also resulted in marked increase in fringed sagewort (Artemisia frigida), and in the appearance of grasses such as squirreltail (Sitanion hystrix) (Ryerson et al., 1970). The long-term effects of an environmental perturbation are well illustrated by these experiments. Fifteen years after pitting or scalping, species change is still dynamic, and fringed sagewort now appears to be decreasing. ${ }^{2}$

Availability of $\mathrm{N}$ and $\mathrm{P}$ is a major factor in determining species distribution (Lunt, 1972; t'Harte, 1949; Sonnevold et al., 1959; Bradshaw et al., 1960), and higher nutrient availability resulting from increased water will play a large role in compositional changes. Fertilizer experiments in the Northern Plains have generally resulted in increases in western wheatgrass and decreases in blue grama (Rogler and Lorenz, 1957; Lorenz, 1970; Wight and Black, 1972).

\section{Genotypic Change}

It is likely that an altered water-nutrient regime would result in genetic change through natural selection within populations on a particular site. Genotypic shifts in response to an altered environment can occur very rapidly (Levins, 1968). The work of Bradshaw and his colleagues on adaptation of grasses to mine spoils has demonstrated this elegantly (see Gregory and Bradshaw, 1965, for a review). Harung (1974) has linked water availability to incorporation of phosphorus into nucleic acids of the desert plant, Anastatica hierochuntica L., providing another possible mechanism for water-linked genetic change.

Little is known concerning ecotypic variation of grasses with respect to water and nutrient requirements. Genotypic differences in water requirement have been shown in orchard grass (Dactylis glomerata) (Keller, 1953; McKell et al., 1960), pubescent (Agropyron trachophorum) and intermediate wheatgrasses (Agropyron intermedium) (Baker and Hunt, 1961). Differential response to magnesium and calcium has been found among populations of bluebunch wheatgrass (Agropyron spicatum) (Main, 1974). However, the extent of such differentiation in nature remains to be determined. Blue grama, for example, appears to vary in its water requirements. In Colorado, it is noted for its ability to respond to favorable growing conditions anytime during the year (Turner and Klipple, 1952), but Ballard and Ryerson (1973) could find no correlation between rainfall and blue grama production in Montana.

Genetic change (including shifts in species) is a common response of nature to a changing environment. It is not a cause for concern unless it results in poorer forage producers or a less stable community. The evidence presented above indicates that community change resulting from increased rainfall in the spring and early summer would be toward higher yielding, more desirable forage species.

\footnotetext{
${ }^{2}$ Personal communication with Harold A. K. Houlton.
} 
Stability is directly related to the degree of success which weather modification operations have. If rain is increased during normally wet years and not affected during drought, the result will be an increase in the amplitude of climatic variation. What this means in an already highly variable environment is not known. If periods of favorable weather result in dominance by more mesic species or genotypes, the ability of the community to respond successfully to drought will involve a much higher compositional flux than at present. Effects of a drought could be more severe; recovery could take longer.

Klages and Rycrson (1965) demonstrated quite clearly some problems which may be encountered. They added water and nitrogen to native range in 1958, 1959, and 1960 with significant increases in yield. 1960 and 1961 were drought years, and by 1962 , grasses in previously fertilized and watered plots had decreased much more than in control plots. Needleand thread was virtually eliminated from experimental plots, while forbs increased. Apparently 3 years of exceptionally favorable growing conditions had reduced this community's ability to withstand unfavorable conditions.

\section{Effect of Added Water on Secondary Productivity}

Cooper and Jolly (1969) suggest that there would be no major insect pest outbreaks as a result of weather modification. Data from irrigated and fertilized range plots in Colorado show insect biomass increases which are generally consistent with increases in forage production (Lavigne and Kumov, 1974).

Among arthropods, response to an ecosystem perturbation is dependent on trophic level and successional status of the community (Hurd and Wolf, 1974). There is significant variation in the response of closely associated grasshopper populations to moisture, temperature, and starvation (Hastings and Pepper, 1964), and there are year-to-year fluctuations in grasshopper populations "which are not the direct result of vegetational changes alone, nor probably of any single environmental factor" (Anderson, 1964). However, Edwards (1960) did find a weak relationship between grasshopper numbers in Saskatchewan and April-August precipitation in the preceding 2 years. Riegert (1968) found grasshopper infestations in Saskatchewan increase in warm, dry weather, whereas cool, moist conditions caused population declines.

Unexplained fluctuations in the populations of small mammals make correlation of their numbers with weather variables very difficult. Okulora and Myskin (1974) found that numbers of the northern red-backed vole (Clethrionomys nutilus) correlated principally with temperature; however, there was an inverse correlation with spring precipitation. Lauenroth and Sims (1973) found shifts in small mammal species composition coupled with significantly smaller biomass in plots which had been irrigated for 2 years.

The response of large herbivores to change in primary production could probably be generalized from cattle data, if cattle data allow a generalization. Ballard and Ryerson (1973) found that in southeast Montana, calf weights were significantly correlated (positively) to growing season and previous year precipitation, but gain of wet cows was not. In a higher rainfall zone in central Montana, there was no relationship between precipitation and cattle weight gains. In a North Dakota study, weaning weights of calves were lowest for years which received the greatest amounts of rainfall from April through July (Johnson et al., 1974). In Colorado, it was found that 1 inch or more rainfall in July or August enhanced steer weight gains significantly (Bose et al., 1975; Sims et al., 1976; cited in Cook, 1975). Whether this would be true in more northerly grasslands, with a smaller component of warm-season grasses, is not clear.

The effect of increased forage on cattle weights will depend largely on its nutritive value. The effects of increased water on the protein content of grasses is quite variable. In many parts of Montana, optimum nutritive content is reached at precipitation levels slightly under average. ${ }^{3}$ Willard and Schuster (1973) found that crude protein of six grasses from the Southern Great Plains was highest when rainfall was adequate for vegetative growth. In the Northern Great Plains, Wight and Black (1974) reported that nitrogen concentration in aboveground biomass declined throughout the growth period independently of rainfall, while phosphorus concentration fluctuated as a function of precipitation. Thomas and Osenbrug (1964) found that the nitrogen content of fertilized grasses was diluted by added water.

Relationship between nutrient content of grasses and precipitation is probably dependent on a number of factors, including grass species and timing of the rainfall. Crude protein percent increases in blue grama, but not in westem wheatgrass, following a summer thunderstorm (Rauzi et al., 1969). In grasslands with a significant component of blue grama, rains in the late summer would perhaps be the most productive from the standpoint of maintaining an adequate nutrient supply. Where western wheatgrass predominates, the evidence indicates this would not be the case; however, it is a question that needs further research. The possibility exists that, given rain in the proper season, warm-season grasses could assume a more important role in northern grasslands.

\section{Other Potential Effects}

\section{Plant Diseases}

Broadbent (1967) reviewed the research on the influence of weather on plant virus diseases, and concluded that it is "considerable and very complex (and) has been adequately studied in relation to very few diseases...."

Aphids and leafhoppers are the principal vectors of plant diseases. Aphids multiply faster in warm, dry summers than in cool, moist ones; however, in dry areas, wet periods which favor the growth of plants may also favor the proliferation of the insects that feed on them (Bradbent, 1967). Curly top virus of beet is increased by spring rains because of increased germination of annual weeds which harbor the virus (Severin, 1939), and in California, rain encourages the growth and subsequent infestation of grasses by aphids which carry cereal yellow dwarf virus (Oswald and Houston, 1953).

Temperature effects on aphids and leafhoppers are mixed. In general, warm temperatures increase aphid movement and thus infection rates (Bald et al., 1950); however, very warm temperatures may result in a cessation of aphid activity altogether (van der Plank, 1944). Hot weather may either increase or decrease the infectivity of leafhoppers, depending on species (Kunkel, 1937; Webb, 1956).

The possible effects of increased moisture on soil-borne pathogens are mixed. Fungi are killed by prolonged conditions that favor activity of anaerobic bacteria. Those without adequate dormant structures may be controlled to a certain extent by low water tensions in surface soils (Bruehl, 1969).

${ }^{3}$ Personal communication with Gene F. Payne. 
Once again, the implication is that timing of added water may be the important factor in determing effects.

\section{Parasites}

The liver fluke is an important parasite of cattle and sheep in many areas. Two conditions are necessary for survival and spread of flukes: (1) an adequate population of the snail, Lynnaea truncatula, which is an essential host during a portion of the fluke's life cycle; and (2) saturated soil for movement of the fluke from host to host (Ollerenshaw, 1967). A concern has been voiced that enhanced rainfall may increase that incidence of liver fluke disease in the Northern Great Plains (now virtually nonexistent). However, Ollerenshaw (1967) has determined that, in England, 3 consecutive months in which rainfall exceeds evaporation are necessary for the fluke to complete its life cycle. In addition, areas of standing water are necessary for suitable snail habitat. It seems unlikely that weather modificaton in the semiarid Great Plains will be successful enough to fulfill either of these conditions.

\section{Runoff}

The amount of runoff produced by increased rainfall will depend on soil type, vegetative cover, and the way in which storm intensity is affected by precipitation modification. On mixed prairie, grassland condition exerts a greater control over infiltration than soil type. On semiarid sites, because of sparse vegetation, the opposite is true (Wolf, 1970).

Wolf (1970) reported that the average 1-hour duration storm was capable of being infiltrated on practically all range sites which he studied. The average 10-minute duration storm would be infiltrated where range conditions were good to excellent, but not when they were fair to poor. Branson and Owen (1970) found that $74 \%$ of the variation in runoff from watersheds underlain by Mancos shale was explained by the proportion of bare soil in the watershed.

The above data indicate that in the short run, runoff in semiarid areas may be increased by precipitation enhancement. However, if increased rainfall results in increased vegetative cover, runoff will decrease proportionately and the long-term effect will be beneficial.

\section{Summary and Conclusions.}

1. Over the short term, aboveground primary production may be increased slightly by spring and early summer rains, but without fertilization maximum yields per inch of added rainfall will probably not exceed $50-110 \mathrm{lb} / \mathrm{acre}$. Increases from added precipitation will probably be considerably higher in years of low than in years of high total growing season precipitation.

2. The long-term effect of added water on primary production will depend on the degree to which decomposition rates are increased, and therefore, the rate at which nutrients are released. Higher rainfall will probably increase nutrient cycling rates; however, research is needed to quantify this effect.

3. Compositional changes will almost certainly occur in the community, the exact nature of which will be highly dependent on the pattern of rainfall increases. Enhanced precipitation in the spring (April and May) will probably result in increased proportions of more mesic, high producing species. Summer and fall rains will probably affect mainly warm-season grasses and forbs; however, research is needed on this point.

4. The effect of increased forage production on livestock weights is not clear. In periods of deficient water, the forage produced by added rainfall will probably result in higher livestock gains. At higher rainfall levels, however, the effect on livestock may be minimal and perhaps even negative. The response will largely be governed by the nutrient content of the forage. Further research is needed on this question.

5. Changes in consumer populations will probably not be dramatic, although small mammal numbers may decline. The effect such a decline would have on community function is not known.

6. Cool, moist weather during the growing season could result in declines in grasshopper populations.

7. Enhancement of precipitation could result in communities which are less able to withstand adverse conditions. If drought periods cannot be affected by weather modification, more extreme fluctuations in the vegetation may result.

8. In the long run, runoff will be reduced in an amount proportionate to increased vegetative cover, providing there isn't a significant increase in storm intensity.

9. There will be both positive and negative effects on diseases of plants. The net effect cannot be predicted.

\section{Literature Cited}

Albertson, F. W., and G. W. Tomanek. 1965. Vegetation changes during a 30-year period in grassland communities near Hays, Kansas. Ecology 46:714-720.

Anderson, Norman L. 1964. Some relationships between grasshoppers and vegetation. Annu. Entomol. Soc. Amer. 57:736-742.

Baker, John N., and O. J. Hunt. 1961. Effects of clipping treatments and clonal differences on water requirements of grasses. J. Range Manage. 14:216-219.

Bald, J. G., D. O. Norris, and G. A. Helson. 1950. Transmission of potato virus diseases. VI. The distribution of the aphid vectors on sampled leaves and shoots. A ust. J. Agr. Res. 1:18-32.

Ballard, William, and D. E. Ryerson. 1973. Impacts of induced rainfall on the Great Plains of Montana-Section 1:Range livestock production. Mont. Agr. Exp. Sta. Res. Rep. 42.

Beatly, Janice C. 1974. Phenological events and their environmental triggers in Mojave Desert ecosystems. Ecology 55:85 6-863.

Bleak, Alvin T., Wesley Keller, and A. C. Hull, Jr. 1974. Range plant yield and species relationships in natural and partially controlled environments. J. Range Manage. 27:396-399.

Bose, D. R., Herb Mann, and C. Wayne Cook. 1975. Grazing research in southeast Colorado 1974. Colo. State Univ. Exp. Sta. Progr. Rep. No. 2 .

Bradshaw, A. D. 1964. Experimental investigations into the mineral nutrition of several grass species. IV. Nitrogen level. J. Ecol. 52:665-676.

Bradshaw, A. D., J. J. Chadwick, D. Jowett, and R. W. Snaydon. 1960. Experimental investigations into the mineral nutrition of several grass species. III. Phosphate level. J. Ecol. 48:631-637.

Branson, F. A. 1956. Range forage production changes on a waterspreader in southeastern Montana. J. Range Manage. 9:187-191.

Branson, F. A., and J. R. Owen. 1970. Plant cover, runoff, and sediment yield relationships on Mancos shale in western Colorado. Water Resources Res. 6:783-790.

Broadbent, L. 1967. The influence of climate and weather on the incidence of plant virus diseases. p. 99-104. In: James A. Taylor (Ed.), Weather and Agriculture. Pergamon Press, London.

Bruehl, G. W. 1969. Factors affecting the persistence of fungi in soil. p. 11-13. In: Roy A. Young and William C. Snyder (Ed.), Nature of the Influence of Crop Residues on Fungus-Induced Root Diseases. Wash. Agr. Exp. Sta. Bull. 716.

Caprio, Joseph M., and Jack S. Williams. 1973. Impacts of induced rainfall on the Great Plains of Montana-Section 4: Agricultural production. Mont. Agr. Exp. Sta. Res. Rep. 42.

Cook, C W. 1975. Possible benefits of weather modification on rangeland production. p. 13-14. In: Lewis O. Grant and John D. Reid (Ed.), Workshop for an Assessment of the Present and Potential Role of Weather Modification in Agricultural Production. Colo. State Univ., Dep. Atmospheric Sci., Fort Collins, Atmospheric Sci. Pap. No. 236. 
Cooper, C. F., and W. C. Jolly. 1969. Ecological effects of weather modification: a problem analysis. Univ. Michigan, School Natur. Resources. Ann Arbor.

Cosper, H. R., and J. R. Thomas. 1961. Influence of supplemental runoff water and fertilizer on production and chemical composition of native forage. J. Range Manage. 14:292-297.

Coupland, Robert T. 1959. Effect of changes in weather conditions upon grasslands in the Northern Great Plains. In: H. B. Sprague (Ed.), Grasslands. Amer. Ass. Advancement Sci. Pub. No. 53.

Dahl, B. E. 1963. Soil moisture as a predictive index to forage yield for the sandhills range type. J. Range Managc. 16:123-132.

DeJong, E., H. J. V. Schappert, and K. B. MacDonald. 1974. Carbon dioxide evolution from virgin and cultivated soil as affected by management practices and climate. Can. J. Soil Sci. 54(3):299-307.

Edwards, R. L. 1960. Relationships between grasshopper abundance and weather conditions in Saskatchewan, 1930-1958. Can. Entomol. 92:619-624.

Garwood, E. A. 1967. Some effects of soil water conditions and soil temperature on the roots of grasses, I, The effects of irrigation on the weight of root material under various swards. J. Brit. Grassland Soc. $22: 176-181$

Goetz, H. 1969. Composition and yields of native grassland sites fertilized at different rates of nitrogen. J. Range Manage. 22:384-390.

Gregory, R. P. G., and A. D. Bradshaw. 1965. Heavy metal tolerance in populations of Agrostis tenuis Sibth. and other grasses. New Phytol. 64:131-143.

Harmsen, G. W., and D. A. Van Schreven. 1955. Mineralization of organic nitrogen in soil. Advances Agron. 7:299-398.

Harung, Wolfram. 1974. The effect of soil water content on the nucleic acids of Anastatica hierochuntica L. Flora (Jena) 163(1/2):156-162.

Hastings, E., and J. H. Pepper. 1964. Population studies on the big-headed grasshopper (Aulocara elliotti). Ann. Entomol. Soc. Amer. 57:216-220.

Hurd, L. E., and L. L. Wolf. 1974. Stability in relation to nutrient enrichment in arthropod consumers of old field successional ecosystems. Ecol. Monogr. 44:465-482.

Johnson, J. E., et al. 1974. A comprehensive evaluation of the effects of added rainfall during the growing season in North Dakota. North Dakota State Univ., Fargo. 227 p.

Justice, J. K., and R. L. Smith. 1962. Nitrification of ammonium sulfate in a calcareous soil as influenced by combination of moisture, temperature, and levels of added nitrogen. Proc. Soil Sci. Soc. Amer. 26:246-250.

Keller, Wesley. 1953. Water requirement of selected genotypes of orchard grass, Dactylis glomerata L. J. Amer. Soc. Agron. 46:495-499.

Klages, M. G., and D. E. Ryerson. 1965. Effects of nitrogen and irrigation on yield and botanical composition of western Montana range. Agron. J. 57:78-81.

Koepf, H. 1952. Bodenkling und bodenatmung. Berichte des Dentscher Wetterdienst in der US-Zone, Nr. 32:34-37.

Kunkel, L. O. 1937. Effect of heat on ability of Cicadula sexnotata (Fall.) to transmit aster yellows. Amer. J. Bot. 24:316-327.

Laude, H. M. 1953. The nature of summer dormancy in perennial grasses. Bot. Gaz. 114:284-292.

Lauenroth, W. K., and P. L. Sims. 1973. Effects of water and nitrogen stresses on a shortgrass prairie ecosystem. Colo. State Univ., IBP Grasslands Biome. Tech. Rep. No. 232.

Lavigne, R. J., and Rabinder Kumov. 1974. Population densities and biomass of above ground arthropods subjected to environmental stress treatments on the Pawnee site, 1973. Colo. State Univ., IBP Grasslands Biome. Tech. Rep. No. 268.

Levins, Richard. 1968. Evolution in changing environments. Princeton Univ. Press, Princeton, N. J. 120 p.

Lorenz, R. J. 1970. Response of mixed prairie vegetation to fertilization and harvest frequency. North Dakota State Univ., Fargo. PhD Diss. 135 p.

Lunt, O. R. 1972. Problems in nutrient availability and toxicity. p. 271-277. In: V. B. Younger and C. M. McKell (Ed.), The Biology and Utilization of Grasses. A cademic Press, New York.

Main, John L. 1974. Differential responses to magnesium and calcium by native populations of Agropyron spicatum. Amer. J. Bot. 61:931-937.

McKell, C. M., E. R. Perrier, and G. L. Stebbins. 1960. Responses of two subspecies of orchardgrass (Dactylis glomerata subsp. lusitanica and judaica) to increasing soil moisture stress. Ecology 41:772-778.
Miller, R D., and D. D. Johnson. 1964. The effect of soil moisture tension on $\mathrm{CO}_{2}$ evolution, nitrification, and nitrogen mineralization. Proc. Soil Sci. Soc. Amer. 28:644-647.

Monson, O. W., and J. R. Queensberry. 1958. Putting floodwaters to work on rangeland. Mont. Agr. Exp. Sta. Bull. No. 543.

Mueggler, W. F. 1972. Plant development and yield on mountain grasslands in southwestern Montana. U.S. Dep. Agr. Forest Serv. Res. Pap. INT-124, 20 p.

Noller, Gary L. 1968. The relationship of forage production to precipitation, cover, and soils in north central Wyoming. Univ. Wyoming, Laramic, PhD Thesis. 153 p.

Nyhan, John W., and K. G. Doxtader. 1974. Decomposition of Bouteloua gracilis plant materials in a grassland ecosystem. Colo. State Univ., IBP Grasslands Biome. Tech. Rep. No. 270.

Okulora, N. M., and A. A. Myskin. 1974. Estimation of the importance of various factors in the population dynamics of the northern red-backed vole, Clethrionomys rutilus. Zool. Z H 52(12):1849-1860.

Ollerenshaw, C. B. 1967. Climatic factors and liver fluke disease. p. 129-135. In: James A. Taylor (Ed.), Weather and Agriculture. Pergamon Press, London.

Oswald, J. W., and B. R. Houston. 1953. Host range and epiphy tology of the cereal yellow dwarf disease. Phytopathology 43:308-313.

Parker, D. T., and W. E. Larson. 1962. Nitrification as affected by temperature and moisture content of mulched soils. Proc. Soil Sci. Soc. Amer. 26:238-242.

Pettit, R. D., and Richard E. Fagan. 1974. Influence of nitrogen and irrigation on carbohydrate reserves of buffalograss. J. Range Manage. 27:279-282

Power, J. F. 1972. Fate of fertilizer nitrogen applied to a Northern Great Plains rangeland ecosystem. J. Range Manage. 25:367-371.

Rauzi, F. 1964. Late spring herbage production on shortgrass rangeland. J. Range Manage. 17:210-222

Rauzi, F., L. I. Painter, and A. K. Dobrenz. 1969. Mineral and protein contents of blue grama and western wheatgrass. J. Range Manage. 22:47-49.

Riegert, Paul W. 1968. A history of grasshopper abundance surveys and forecasts of outbreaks in Saskatchewan. Memoirs Entomol. Soc. Can. 52:2-99.

Rogler, G. A., and R. J. Lorenz. 1957. Nitrogen fertilization of Northern Great Plains grasslands. J. Range Manage. 22:384-390.

Rogler, George A., and Howard J. Haas. 1947. Range production as related to soil moisture and precipitation on the Northern Great Plains. J. A mer. Soc. Agron. 39:378-389.

Ryerson, D. E., J. E. Taylor, L. O. Baker, and others. 1970. Clubmoss on Montana rangelands. Mont. Agr. Exp. Sta. Bull. 645. 116 p.

Severin, H. H. P. 1939. Factors affecting curly-top infectivity of the beet leafhopper, Eutettix tenellus. Hilgard ia 12:497-530.

Shiflet, Thomas N., and H. E. Dietz. 1974. Relationship between precipitation and annual rangeland herbage production in southeastern Kansas. J. Range Manage. 27:272-276.

Sims, Phillip L. B. E. Dahl, and A. H. Denham. 1976. Vegetation and livestock response at three grazing intensities on sandhill rangeland in eastern Colorado. Colo. State Univ., Exp. Sta. Bull. (manuscript in preparation).

Smika, D. E., H. J. Haas, and J. F. Power. 1965. Effects of moisture and nitrogen fertilizer on growth and water use by native grass. Agron. J. 57:483-486.

Smith, Freeman. 1972. Growth response of blue grama to thunderstorm rainfall. Colo. State Univ., IBP Grasslands Biome. Tech. Rep. No. $157.31 \mathrm{p}$.

Smoliak, S. 1956. Influence of climatic conditions on forage production of shortgrass rangeland. J. Range Manage. 9:89-91.

Sonnevold, F., A. A. Kruyne, and D. M. DeVries. 1959. Influence of phosphate on the botanical composition and on the grade of quality of herbage. Neth. J. Agr. Sci. 7:40-50.

Soulides, D. A., and F. E. Allison. 1961. Effect of drying and freezing soils on $\mathrm{CO}_{2}$ production, available mineral nutrients, aggregation, and bacterial population. Soil Sci. 91:291-298.

Sundberg, Eric S. 1974. An in situ evaluation of soil water sensors. Colo. State Univ., IBP Grasslands B iome. Tech Rep. No. 264. 124 p.

t'Harte. 1949. Kartering val landbouwkind ige grasland typen in het lage midden van friesland. Ned Kruidk, Arch. 56:21-22.

Thomas, J. R., and A. Osenbrug. 1964. Interrelationships of nitrogen, phosphorus, and seasonal precipitation in the production of brome grass-crested wheatgrass hay. U.S. Dep. Agr. Prod. Res. Rep. No. 82. $27 \mathrm{p}$. 
Turner, G. T., and G. E. Klipple. 1952. Growth characteristics of blue grama in northeast Colorado. J. Range Manage. $5: 22-28$.

Valentine, K. A. 1947. Effect of water retaining and water spreading structures in revegetating semi-desert rangeland. New Mexico Agr. Exp. Sta. Bull. No. 341.

van der Plank, J. E. 1944. Production of seed potatoes in a hot, dry climate. Nature, Land 15 3:5 89-590.

Van Dyne, George M. 197.5. An overview of the ecology of the Great Plains grasslands with special reference to climate and its impact. Colo. State Univ., IBP Grasslands Biome. Tech. Rep. No. 290.93 p.

Weaver, J. E., and F. W. Albertson. 1939. Major changes in grassland as a result of continued drought. Bot. Gaz. 100:576-591.

Weaver, T. H. 1975. Effects of precipitation modification on Idaho fescue meadows. 28 th Annu. Meeting Soc. Rangc Managc., Mcxico City, Feb. 1975.

Webb, R. E. 1956. Relation of temperature to transmission of the potato leaf roll virus. Phytopathology 46:470.

White, E. M., and D. G. Moore. 1972. Nitrates in South Dakota range soils. J. Range Manage. $25: 27-29$.
Wiant, H. V., Jr. 1967. Influence of moisture content on soil respiration. J. Forest. $65: 902-903$.

Wight, J. Ross, and A. L Black. 1972. Energy fixation and precipitation use efficiency in a fertilized rangeland ecosystem of the Northern Great Plains. J. Range Manage. 25:376-380.

Wight, J. Ross, and A. L. Black. 1974. Nitrogen and phosphorus, uplake and soil water use in a mixed prairie plant community. Unpublished Manuscript, Agr. Res. Serv. Sidney, Mont.

Wildung, R. E., T. R. Garland, and R. L. Schmidt. 1973. Influence of environmental factors on the respiration rate of grassland soils-a model. Colo. State Univ., IBP Grasslands Biome. Tech. Rep. No. 212.

Williams, J. S. 1953. Seasonal trends of minerals and protein in prairie grasses. J. Range Manage. 6:100-108.

Willard, E. E., and J. L. Schuster. 1973. Chemical composition of six Southern Great Plains grasses as related to season and precipitation. J. Range Manage. 26:37-38.

Wolf, D. N. 1970. Grassland infiltration phenomena. Colo. State Univ., IBP Grassland s B iome. Tech. Rep. No. 54. 